\title{
Case Study: Trademark Infringement Issues
}

Michael Cosgrove, University of Dallas, USA
Daniel Marsh, University of Dallas, USA

J.F. Chester, Klemchuk Kubasta LLP, USA

Sean Cosgrove, Federal Government, USA

\begin{abstract}
This is a case study of trademark infringement disputes. One of the authors (M. Cosgrove) incorporated The Econoclast, Inc. in 1979. The company provides capital market publications to financial and nonfinancial institutions, and owns the trademark Econoclast ${ }^{\circledR}$. Over the years, others have attempted to use the same name for similar services. This case study presents the practical steps that Cosgrove undertook to prevent infringement of his trademark in various cases that occurred since our prior paper was published in 2005 (Cosgrove, Marsh and Chester.) The paper also explains the basics of trademark law, the meaning of trademark infringement, and obligations of the trademark owner.
\end{abstract}

Keywords: Trademark Law; Econoclast ${ }^{\circledR}$; Intellectual Property; Infringement; U.S. Patent and Trademark Office; Infringers; Lanham Act; Plagiarism; Property Rights; Violators

\section{INTRODUCTION}

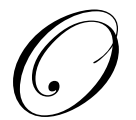

ne purpose of a trademark is to provide protection to customers by ensuring that goods and services they purchase are actually manufactured or provided by the companies associated with the marks. By granting trademark owners the exclusive right to use certain marks to identify their goods and services, trademark law allows a firm to distinguish its products and services from that of other firms. This is a method of branding. The value of a trademark to its owner is dependent on a number of factors, such as the size of the market created for the branded product, as well as the novelty or uniqueness of the mark itself.

Trademark protection can arise through common law right by merely using the mark in commerce or via registration at a national office. Both methods afford similar protection, although the requirements for obtaining and retaining protections, as well as the geographic limits of trademark rights, are different for registered trademark owners versus owners of purely common law trademark rights. For registered marks, the period of protection varies, but a trademark can be renewed indefinitely beyond the time limit by payment of additional fees. Trademark protection is enforced by the courts which, in most countries, have the authority to block trademark infringement.

Trademarks promote enterprise, both locally and globally, by providing owners of trademarks with recognition and profit. Trademark protection also hinders the efforts of unfair competitors, such as counterfeiters, to use similar distinctive signs to market their products and/or services. Trademark law allows people with skill and enterprise to produce and market goods and services more profitably, thereby facilitating both domestic and international trade. Moreover, trademarks can protect consumers from unwittingly paying a premium for inferior products.

Trademarks can apply to more than just names. Trademarked items may include a combination of words, letters, numerals, symbols, colors, and artwork. In addition to trademarks identifying the commercial source of goods or services, several other categories of marks exist. Collective marks are owned by an association whose members use them to identify themselves with a level of quality and other requirements set by the association. Examples of such associations would be those representing accountants and engineers. Also, certification marks, such as Underwriters Laboratories or the Good Housekeeping Seal, are protected trademarks which are used to identify products that meet the specific standards of those certifying entities. 
A trademark is registered by filing an application with the appropriate national or regional trademark office. The application must contain a clear reproduction of the mark filed for registration, including any colors, forms, or three-dimensional features. The application must also contain a list of goods and/or services to which the mark would apply. The mark must fulfill certain conditions in order to be protected as a trademark or other type of mark. It must be distinctive so that consumers can distinguish it as identifying a particular product, as well as from trademarks identifying other products. It must neither mislead nor deceive customers or violate public order or morality.

In addition, trademark law recognizes the principle of priority; that is, the rights applied for cannot be the same as, or "confusingly similar" to, rights already granted to another trademark owner. Whether a mark is confusingly similar to a pre-existing mark is determined through search and examination by the national office or by the opposition of third parties who claim similar or identical rights.

Most countries in the world register and protect trademarks. Each national or regional office maintains a Register of Trademarks which contains full application information on all registrations and renewals, facilitating examination, search, and potential opposition by third parties. The effects of such a registration are, however, limited to the country (or, in the case of a regional registration, countries) concerned.

In order to avoid the need to file trademark registration applications separately with each national or regional office, WIPO (The World Intellectual Property Organization) administers a system of international registration of marks. This system is governed by two treaties - the Madrid Agreement Concerning the International Registration of Marks and the Madrid Protocol. A person who is a resident of a country party to one or both of these treaties may, on the basis of a registration or application with the trademark office of that country, simultaneously apply to register that mark in some or all of the other countries of the Madrid Union. At present, more than 60 countries are party to one or both of the agreements. Although the U.S. has been a part of the Madrid Protocol for some time, the USPTO has only recently enacted procedures for handling Madrid Protocol applications.

This introduction to trademarks is taken, in part, from the World Intellectual Property Organization. Information on obtaining a trademark can be obtained from United States Patent and Trademark Office.

\section{FRAMEWORK FOR TRADEMARKS}

The objective of intellectual property protection is to create incentives that maximize the difference between the value of the intellectual property that is created and used and the social cost of its creation, including the cost of administering the system (Besen, 1991).

Intellectual property can be protected by patents, copyrights and trademarks. Trademark protection doesn't have a constitutional footing, while patents and copyrights do. State law is the origin of trademarks; Federal trademark protection was passed in 1870 , but that particular act was ruled unconstitutional. But in terms of history, the Romans, Greeks and others used different markings to indicate who made items such as pottery or bricks. In the Middle Ages, trade guilds employed markings to identify who made a particular product. The 1946 Lanham Act is the basis of the modern U.S. trademark system which spelled out the major requirements for registration and maintenance of ownership.

The purpose of trademark law is to prevent confusion in the minds of the consuming public as to the source of a particular good and/or service. The owner of a trademark has spent time and resources marketing goods and services identified by the mark. And the purpose of doing that is to have the mark identified with only those goods and services to the exclusion of other goods and services. In monopolistic competition, trademarks or branding, can be very useful as a method to help differentiate close but imperfect substitutes. The trademark holder often must work to prevent others from using the trademark and benefiting from prior use of the trademark. Using someone else's trademark without permission, known as infringement, will likely cause confusion in the minds of the consuming public. 
It is not necessary to prove actual confusion of unique customers in order to prove trademark infringement. Proving likelihood of confusion in the market satisfies the requirement so that similar marks in physical design could constitute cases of infringement (Besen, 1991).

In the United States, trademark does not need to be registered for the owner to prevent others from using it, but Federal registration does provide legal advantages to the trademark holder when pursuing infringers. One advantage is that it serves as public notice of the existence of the registrant's mark, which prevents anyone from claiming that they did not know the mark existed. This notice is constructively assumed to be given to anyone within the territorial jurisdiction of the registering body. For example, a mark registered with the U.S. Patent \& Trademark Office (USPTO) would be constructive notice to anyone within the United States, plus its territories and protectorates.

Trademarks must be protected by the trademark holder to prevent them from falling into the public domain and causing the trademark holder to lose protection (Iowa State University). For example, the term "Kleenex" has become so ubiquitous that people often refer to non-Kleenex brand facial tissue as "Kleenex." If left unchecked, the mark could become synonymous with "facial tissue" and thus would become generic. If so, the mark loses its uniqueness and would thus lose its protection under trademark law.

An earlier case was aspirin, which originally was a trademark of Bayer for their drug containing acetylsalicylic acid. Aspirin is now a generic name. Another example is "xerox," (lower case spelling) used as an adjective or verb, derived from the trademarked "Xerox," used by the Xerox Corporation to describe its process of dry ink copying. Xerox has spent millions of dollars in recent years to reinforce its brand and deter generic use of the term "xerox" for copies made on copiers other than those made by Xerox.

\section{CASE STUDY}

The Econoclast, Inc. was incorporated by Professor Cosgrove in 1979 and has provided capital market publications to institutions since that time. It is independent of the University of Dallas. Professor Cosgrove also has been a contributor to Blue Chip Economic Indicators since 1983 as well as to the Western Blue Chip State Economic Forecast since1989. He has been a contributor to The Wall Street Journal forecasting survey since 1994. Cosgrove also contributes to various other entities including Reuters U.S. Economic Survey and MacroMarkets Home Price Expectations Survey. In other words, Cosgrove has spent significant time and resources in developing customer recognition and goodwill in the Econoclast ${ }^{\circledR}$ mark. Note the Cosgrove, Marsh and Chester paper for infringement cases for 2005 and earlier.

One of the cases from the 2005 study had not been resolved at the time that paper was published. In brief, that case involved Dr. John Palmer, a professor at the University of Western Ontario, who had started a blog on economics called "Econoclast." U.S. trademark law does not apply in Canada, so legally Professor Cosgrove had no recourse. Nonetheless, Dr Palmer was sent a cease and desist letter. The question in this case is whether Dr. Palmer felt he had a moral duty not to engage in trademark infringement, even if he did not have a legal duty. He subsequently changed the name of his blog to "The Eclectic Econoclast", but that did not alter the trademark confusion issue with Econoclast ${ }^{\circledR}$. In the meantime, Cosgrove had employed a law firm to obtain a trademark in Canada. Dr. Palmer eventually altered the name of his blog to "ElecEcon" to avoid infringing on Cosgrove's Econoclast ${ }^{\circ}$ Canadian trademark.

An interesting aspect of that case was that the American Economic Association, based in the United States, initially hosted a link to the Canadian Econoclast site, which meant that the American Economic Association appeared to be infringing on a U.S. trademark. That issue was resolved with AEA. But the possible infringement issue with the AEA was a surprise in that it took a lengthy amount of time to resolve the possible infringement issue. Professors expect students to do an internet search to avoid the possibility of plagiarism and/or a copyright/trademark violation before submitting term papers. The AEA presents itself as the public spokesman for academic economists in the United States and normally adheres to the highest ethical and intellectual standards, but it is not clear to this day what level of due diligence the AEA engages in before adding links to its website. 


\section{Illustration I - Possible International Infringement}

Dr. Ron Woods in Australia had a site called Econoclast. U.S. trademark law does not apply in Australia, so legally Professor Cosgrove had no recourse. Mr. Woods was sent a cease and desist letter anyway. The question in this case is whether Mr. Woods felt he had a moral duty not to engage in trademark infringement, even if he did not have a legal duty as was the case with Dr. Palmer in Canada.

This situation, like the one in Canada, introduced an interesting legal issue. The internet is essentially a global community in which national borders become meaningless, yet laws defining intellectual property rights can only be enforced within national jurisdictions. Even though U.S. trademark law is not applicable in Australia, residents of the U.S. can access the site in Australia, and Econoclast ${ }^{\circledR}$ is a registered trademark in the U.S. and in Canada. Since Econoclast ${ }^{\circledR}$ is available via the internet, the mark, in one sense, has already been published in Australia. Thus, it may be possible that Australian law could afford some protection to Econoclast ${ }^{\circledR}$ under common law.

In addition the USPTO considers web pages to be valid evidence of "use in commerce" for purposes of applying for Federal trademark registration. However, the question remains as to the geographic limits of this "use in commerce."

Professor Cosgrove found it necessary to employ a law firm in an attempt to obtain a trademark in Australia. That was in the 2006-2007 timeframe. Mr. Woods also decided to apply for a trademark for Econoclast in Australia. At one point, both applications were pending for the right to own the Econoclast trademark registration in Australia.

After significant resources were allocated to that issue, Mr. Woods allowed his application to expire and the Cosgrove Econoclast ${ }^{\circledR}$ application was registered in Australia in August 2007. That should have resolved it, but there continues to be a likely infringement issue with Mr. Woods.

\section{Illustration II - Likely Infringement within the U.S.}

Professor James K. Galbraith at the Lyndon B. Johnson School of Public Affairs, at the University of Texas at Austin, was writing a column entitled Econoclast for Mother Jones, a nonprofit magazine. Professor Cosgrove noticed the likely infringement issue in 2007 and sent cease and desist letters by certified mail to Dr. Galbraith, John Harris at Mother Jones, as well as to James Steinberg, the then Dean at the Lyndon B. Johnson School of Public Affairs on May 25, 2007.

Mr. Harris, President and Publisher of Mother Jones, responded in writing on May 31 saying that they had no idea the word "Econoclast" was trademarked and said, "we are happy to assure you that we will not" (use Econoclast.) No written response was received from Dr. Galbraith or Dean Steinberg. Mother Jones stopped using Econoclast ${ }^{\circledR}$ with a minimum of transaction costs. It may be that Mother Jones had no idea Econoclast ${ }^{\circledR}$ was federally registered and Dr. Galbraith may have been similarly ignorant. However, professors lecture their students on the importance of not plagiarizing and violating trademark/copyright law. Professors, in cases, may not accept an excuse such as, "Gee, I had no idea." An internet search would have resolved it on the part of Mother Jones and/or Dr. Galbraith. Moreover, as cited above, the existence of a federal registration is constructive notice to everyone in the United States of the existence of Professor Cosgrove's ownership of Econoclast ${ }^{\circledR}$.

Below is a copy of the partial home page of Dr. Galbraith that was posted at LBJ School in May 2007:

James K. Galbraith

Lloyd M. Bentsen, Jr. Chair in Government/Business Relations and Professor of Government

Contact Info:

Phone: 512-471-1244

Email: galbraith@mail.utexas.edu

Office: SRH 3.237 
Spring 2007 Office Hours:

Tuesdays, 1:30-3:30 p.m. or by appointment

James K. Galbraith teaches economics and a variety of other subjects at the LBJ School. He holds degrees from Harvard (B.A. magna cum laude, 1974) and Yale (Ph.D. in economics, 1981). He studied economics as a Marshall Scholar at King's College, Cambridge in 1974-1975, and then served in several positions on the staff of the U.S. Congress, including Executive Director of the Joint Economic Committee. He was a guest scholar at the Brookings Institution in 1985. He directed the LBJ School's Ph.D. Program in Public Policy from 1995 to 1997. He directs the University of Texas Inequality Project, an informal research group based at the LBJ School.

Galbraith has co-authored two textbooks, The Economic Problem with the late Robert L. Heilbroner, and Macroeconomics with William Darity, Jr. He is the author of Balancing Acts: Technology, Finance and the American Future (1989) and Created Unequal: The Crisis in American Pay (1998). His most recent book, Inequality and Industrial Change: A Global View (Cambridge University Press, 2001), is co-edited with Maureen Berner and features contributions from six LBJ School Ph.D. students.

Galbraith maintains several outside connections, including serving as a Senior Scholar of the Levy Economics Institute and as Chair of the Board of Economists for Peace and Security. He writes a column called "Econoclast" for Mother Jones, and occasional commentary in many other publications, including The Texas Observer, The American Prospect, and The Nation. He is an occasional commentator for Public Radio International's Marketplace...

Either Dr. Galbraith or an assistant must have entered this information about Econoclast ${ }^{\circledR}$ - Cosgrove's trademark. Professors expect students to do an internet search to avoid the possibility of plagiarism and/or a copyright/trademark violation before submitting term papers. The experience of Professor Cosgrove with his Canadian case, the American Economic Association experience and his experience with Galbraith suggests that perhaps professors should follow their own suggestions to their students and check the internet for copyright/trademark infringement issues. Dr. Galbraith no longer has Econoclast on his home page.

But the Bill Moyers Journal, in a 2008 link, still had Econoclast associated with Dr. Galbraith:

http://www.pbs.org/moyers/journal/10242008/profile.html

Bill Moyers Journal

October 24, 2008

When last week began, minders of the world's major economies had gathered together to hammer out a coordinated strategy for stabilizing the world economy. In response, investors kicked off the week with the biggest single-day percentage gain in the Dow Jones industrial index in seventy-five years. Thus commenced a roller-coaster week on Wall Street, with stock markets gaining and losing huge amounts daily before ending low on Friday.

Markets this week remained volatile, as traders reacted to a steady stream of bad economic news in the US and abroad. Economist James K. Galbraith joins Bill Moyers on the JOURNAL to help make sense of the state of the economy, the efficacy of the bailouts, and how we got here.

James K. Galbraith is currently the Lloyd M. Bentsen Chair in Government and Business Relations and Professor of Economics at the LBJ School of Public Affairs at the University of Texas at Austin. He holds degrees from Harvard (B.A. magna cum laude, 1974) and Yale (Ph.D. in economics, 1981). He studied economics as a Marshall Scholar at King's College, Cambridge in 1974-1975, and then served in several positions on the staff of the U.S. Congress, including as the Executive Director of the Joint Economic Committee. He was a guest scholar at the Brookings Institution in 1985 before joining the faculty at the University of Texas. From 1995 to 1997 he directed the LBJ School's Ph.D. Program in Public Policy. He held a Fulbright Distinguished Visiting Lectureship in China in the summer of 2001 and was named a Carnegie Scholar in 2003. His recent research has focused on the measurement 
and understanding of inequality in the world economy, and leads an informal research group called the University of Texas Inequality Project with several of the school's distinguished graduate students.

Professor Galbraith has co-authored several books including: BALANCING ACTS: TECHNOLOGY, FINANCE AND THE AMERICAN FUTURE (1989), CREATED UNEQUAL: THE CRISIS IN AMERICAN PAY (1998), INEQUALITY AND INDUSTRIAL CHANGE: A GLOBAL VIEW (Cambridge University Press, 2001), which was coedited with Maureen Berner and features contributions from six LBJ School Ph.D. students, UNBEARABLE COST: BUSH, GREENSPAN AND THE ECONOMICS OF EMPIRE (2006) and his latest book THE PREDATOR STATE: HOW CONSERVATIVES ABANDONED THE FREE MARKET AND WHY LIBERALS SHOULD TOO (2008).

Professor Galbraith maintains several outside connections, including serving as a Senior Scholar of the Levy Economics Institute and as Chair of the Board of Economists for Peace and Security. He writes a column called "Econoclast" for MOTHER JONES, and occasional commentary in many other publications, including The TEXAS OBSERVER, THE AMERICAN PROSPECT, and THE NATION. He is an occasional commentator for Public Radio International's MARKETPLACE. Published October 24, 2008.

An issue with owing trademark rights is that it is the responsibility of trademark owners to be vigilant in ensuring that their mark is not being infringed and to bear the burden of asserting their rights. The USPTO doesn't police infringement or assert the rights of registered trademark owners. In addition, the USPTO will not advance a case in court on behalf of trademark owners.

The USPTO also considers web pages to be valid evidence of "use in commerce" for purposes of applying for Federal trademark registration. However, the question remains as to the geographic limits of this "use in commerce."

\section{Illustration III - A Case which may or may not be Infringement}

In October 2009, Professor Cosgrove happened to be watching CNBC one evening and Brian Domitrovic was introduced as having written Econoclasts, a recent book. Mr. Domitrovic is an assistant professor at Sam Houston State University, Huntsville, Texas, in the History Department. Professor Cosgrove has been using Econoclast ${ }^{\circledR}$ since 1979 and is always surprised to learn of professors at other universities who suddenly decide to adopt Econoclast ${ }^{\circledR}$ for their personal use.

An attorney, at the time, suggested that book titles were exempt from trademark law. A general legal principle is that while the contents of books may be copyrighted, book titles per se cannot be copyrighted. You can write a new book and call it The Godfather or Jaws if you wish. There still might be an infringement issue, but it could hinge on technical details.

The relationship between trademark law and book titles can be divided into two basic categories. The first category - books in a series - typically follows traditional trademark principles, whereas the second category - titles to individual books or novels - is not afforded trademark protection. For example, The Seven Habits of Highly Effective People is a registered trademark of a series of books, pamphlets, audio tapes and other media describing personal and leadership development skills. The Seven Habits series of books and other media can register a trademark because it is a series of books and other media that are linked by the title and content with a certain format of leadership development skills marketed by the publisher.

As mentioned above, the Lanham Act provides trademark protection to words or phrases that identify a product or service because it is associated with that product or service. In the words of the courts, it is "distinctive" more than just "descriptive." A single published work cannot be inherently distinctive because the words of the title identify a book, not its source (Herbko 2002). "Titles of single works merely serve to describe the work no matter how unrelated to the book contents." (Herbko 2002, Cooper 1958) While a single work of fiction is not afforded protection under trademark law, a single book title may be protected under copyright law until the expiration of the copyright. 
In this case, Econoclast ${ }^{\circledR}$ is a registered trademark of Econoclast, Inc., whereas the book titled Econoclasts: The Rebels Who Sparked the Supply-Side Revolution and Restored American Prosperity, could not receive trademark status because it is a "single published work." (Herbko 2002) It could be that Econoclasts: The Rebels Who Sparked the Supply-Side Revolution and Restored American Prosperity may possibly infringe on the Econoclast mark if the book discusses similar types of economic theories regularly espoused in the Econoclast and could increase the likelihood of confusion from the customer's point of view.

However, it did not seem worth it to hire an attorney because Mr. Domitrovic had not used a major publisher. Nonetheless, a letter was sent to David E. Payne, Ph.D., Provost and VP of Academic Affairs at Sam Houston State University, with a copy to Dr. Terry Bilhartz, Chair, History Department at Sam Houston State.

Provost Payne responded essentially stating he had checked and this is an issue with Dr. Domitrovic if Dr. Cosgrove should decide to pursue it. The History Department at Sam Houston State University lists the book on its website: Econoclasts: The Rebels Who Sparked the Supply-Side Revolution and Restored American Prosperity ... by Dr. Domitrovic. It isn't clear what role Sam Houston State has in this.

Again this case may not technically be infringement or plagiarism, but Professor Cosgrove is nonetheless surprised by the frequency with which university professors suddenly have the insight to use Econoclast ${ }^{\circledR}$, in particular, since most professors lecture their students on the importance of avoiding plagiarism and/or copyright/trademark violations before submitting term papers.

\section{Illustration IV- Possible International and likely U.S. Infringement}

In early August 2010, we happened to search the internet for possible infringements of Econoclast ${ }^{\circledR}$. Much to our surprise, we found that the Financial Times had a blog called Econoclast. Shortly after we noticed it, a friend sent us an email that contained the following:

\section{Financial Times}

The Financial Times has launched a new blog called Econoclast which will focus on macroeconomics, economic policymaking and the financial markets. It will be written by Gavyn Davies, a macroeconomist who is now chairman of Fulcrum Asset Management and co-founder of Prisma Capital Partners. He was the head of the global economics department at Goldman Sachs from 1987-2001 and was chairman of the BBC from 2001-2004. Gavyn also served as an economic policy adviser in No 10 Downing Street, an external adviser to the British Treasury and a visiting professor at the London School of Economics. His blog can be read online at http://blogs.ft.com/econoclast// and followed on Twitter at wwwtwitter.com/fteconoclast

The Financial Times is one of the leading business newspapers in the world. If some entity started a blog called the Financial Times, one might expect that the Financial Times legal team would attempt to punish that entity to the fullest extent possible as an example so that others might be less likely to do something similar.

On August 3, Cosgrove sent emails to the COO of Prisma Capital Partners, since Mr. Davies is associated with that entity, and several individuals at the Financial Times. On August 4, we received an email labeled "Private \& Confidential" from a Senior Legal Counsel at the Financial Times. The essence of the letter was that the Financial Times had made the decision to use Econoclast and not Prisma Capital or Mr. Davies.

That case ended with very limited transaction costs on Cosgrove's part, but the interesting question is, "Why would the Financial Times start a blog called Econoclast ${ }^{\circledR}$ when it is very clear to anyone checking for possible conflicts that the Econoclast ${ }^{\circledR}$ was already trademarked?"

\section{SUMMARY}

Trademarks are a form of intellectual property, similar to patents and copyrights. Infringement of trademarks is a violation of property rights under U.S. law and international conventions. One of the authors 
(Cosgrove) incorporated The Econoclast which owns the trademarked name Econoclast ${ }^{\circledR}$, the title of his capital markets service. Since this trademark has been in use since 1979, violators cannot use the excuse that it escaped their attention because it is so new.

Nonetheless, most of the infringement cases cited here were perhaps inadvertent. The Econoclast ${ }^{\circledR}$ is not as well known as The Wall Street Journal and Professor Cosgrove is not a celebrity economist of the likes of Paul Krugman or Larry Summers.

On the other hand, modern technology has made the cost of searching for prior trademark claims exceedingly low. It is surprising that there seems to be a high degree of carelessness on the part of people and entities that should know enough to run an internet search to determine if there might be a copyright/trademark issue. Are people and entities that careless, or do they somehow think trademark and/or patent law doesn't apply to them? Fortunately, the majority of possible infringements of the Econoclast ${ }^{\circledR}$ were halted at low cost with ceaseand-desist letters. But at the time of this writing, there does remain a potential dispute with one of the cases.

\section{AUTHOR INFORMATION}

Michael Cosgrove earned his Ph.D. at Ohio State University. Currently he is professor in the College of Business, University of Dallas. Mike is also principal at Econoclast, a Dallas-based capital markets firm.

Daniel Marsh, ABD, Southern Methodist University. Currently he is adjunct professor in the College of Business, University of Dallas. He is also a writer of popular works in his spare time.

J. F. (Jim) Chester is an intellectual property and international business attorney in Dallas, as well as adjunct professor of law at Baylor University Law School. Jim earned his JD at South Texas College of Law, and his LL.M in international economic law from the University of Houston Law Center.

Sean Cosgrove earned his JD at Texas Wesleyan University School of Law and is an attorney in Dallas, Texas.

\section{REFERENCES}

1. Besen, Stanley M. and Raskind, Leo J., "An Introduction to the Law and Economics of Intellectual Property", The Journal of Economic Perspectives, Vol. 5, (1), 1991, 2-27.

2. $\quad$ In re Cooper, 45 C.C.P.A. 932, 254 F.2d 611, 615 (Fed. Cir. 1958).

3. Cosgrove, Michael, Marsh, Daniel, Chester, J.F. “Case Study: Potential Trademark Infringements”, Journal of Business \& Economics Research, Vol. 3, (12), 2005, 7-13.

4. $\quad$ Herbko Int'l, Inc. v. Kappa Books, Inc., 308 F.3d 1156, 1163 (Fed. Cir. 2002).

5. Intellectual Property Organization -- http://www.wipo.int/activities/en/development_iplaw.html

6. Iowa State University -- http://www.trademark.iastate.edu/basics/

7. United States Patent and Trademark Office, http://www.uspto.gov/index.html 